\title{
L- Karnitinin Sitotoksik ve Genotoksik Etkilerinin Allium cepa Kök Ucu Testi ile Değerlendirilmesi
}

\author{
Siğnem ONEY-BIROL ${ }^{1}$ (D), Fatma GÜNDÜZ 2 \\ 1,2Burdur Mehmet Akif Ersoy Üniversitesi, Fen Edebiyat Fakültesi, Moleküler Biyoloji ve Genetik Bölümü, 15030, Burdur, Türkiye \\ ${ }^{1}$ https://orcid.org/0000-0002-0828-5739, ${ }^{2}$ https://orcid.org/0000-0002-2642-8916 \\ 凹: sobirol@mehmetakif.edu.tr
}

\section{ÖZET}

L-karnitin organizma için enerji metabolizmasında görevli doğal olarak sentezlenen endojen bir moleküldür. Bu çalışmada, Allium cepa L. (soğan) testi ile l-karnitinin muhtemel genotoksik etkilerini ortaya koymak amaçlanmıştır. Farklı dozlarda (100, 250, 500, 750, 1000, $1250 \mathrm{mg} / \mathrm{L}$ ) l-karnitinin mitotik aktivite ve kromozom davranışları üzerine etkilerine dair yapılan çalışmada kontrol grubuna (0 mg/L l-karnitin) (0.20) oranla $1250(0.22), 1000(0.25)$ ve $250(0.21) \mathrm{mg} / \mathrm{L}$ l-karnitin uygulamasının mitotik aktiviteyi teşvik ettiği, $500(0.11) \mathrm{mg} / \mathrm{L}$ l-karnitin uygulamasının ise hücre bölünmesini baskıladığı belirlenmiştir. L-karnitinin genotoksik etkisi bakımından, kontrol grubu soğan kök meristematik hücrelerinde kromozom aberasyonlarına rastlanmazken, tüm uygulama gruplarında farklı tipte (düzensiz profaz, mikronukleus, yanlış kutuplaşma, geri kalmış kromozomlar, anafaz ve telofaz köprüsü, çift nukleuslu hücre) ve sayıda anormal kromozomlara rastlanmıştır. Bu çalışmada ortaya konulan sonuçlar, gıda takviyesi olarak sıklıkla tüketilen l-karnitinin $1000 \mathrm{mg} / \mathrm{L}$ 'lik dozunun mitotik aktiviteyi teşvik etmek suretiyle hücre bölünmesini artırdığı ve kromozomlar üzerindeki genotoksik hasarı indirgemesine rağmen $500 \mathrm{mg} / \mathrm{L}$ 'lik l-karnitin dozunun hücrelerde toksik etkiye sahip olduğu ve kromozom yapısı üzerinde aberasyonların oranını artırdığını göstermiştir.

\section{Araştırma Makalesi}

Makale Tarihçesi

Geliş Tarihi : 13.02 .2019

Kabul Tarihi : :28.03.2019

Anahtar Kelimeler

Hücre bölünmesi

Genotoksisite

Kromozomal aberasyon

L-karnitin

Mitotik aktivite

\section{Assessment of Cytotoxic and Genotoxic Effects of L-Carnitine in Allium cepa Root Tip Assay}

\section{ABSTRACT}

L-carnitine is an endogenous molecule that is naturally synthesized and involved in energy metabolism of the organism. In this study, it was aimed to reveal potential genotoxic effects of l-carnitine using Allium cepa L. (onion) test. To investigate effects of different doses of l-carnitine $(100,250,500,750,1000,1250 \mathrm{mg} / \mathrm{L})$ on mitotic activity and chromosome structure, $1250(0.22), 1000(0.25)$ and $250(0.21)$ $\mathrm{mg} / \mathrm{L}$ of l-carnitine doses stimulated mitotic activity compared to the control group (0 mg/L l-carnitine) (0.20), however, it was determined that $500 \mathrm{mg} / \mathrm{L}$ l-carnitine concentration (0.11) inhibited cell division. Genotoxic effect of l-carnitine were compared with all studied concentrations and although there were no chromosome aberrations in the control group of onion meristematic cells, numerious chromosome aberations were found in all application groups of 1carnitine concentrations such as disorderly prophase, micronucleus, fault polarization, lagging chromosomes, anaphase and/or telophase bridges and denucleated cells. The results presented in this study showed that dose of $1000 \mathrm{mg} / \mathrm{L}$ of l-carnitine, which is frequently used in diets as a dietery supplement, stimulated mitotic activity via increasing cell division and reduced genotoxic damage on chromosomes, however $500 \mathrm{mg} / \mathrm{L}$ of l-carnitine dose had a toxic effect on cells and increased aberration rates on chromosome structure.

\section{Research Article}

$\begin{array}{ll}\text { Article History } & \\ \text { Received } & : 13.02 .2019 \\ \text { Accepted } & : 28.03 .2019\end{array}$

Keywords
Cell division
Chromosomal aberration
Genotoxicity
L-carnitine
Mitotic activity

To Cite : Oney-Birol S, Gündüz F 2019. L- Karnitinin Sitotoksik ve Genotoksik Etkilerinin Allium cepa Kök Ucu Testi ile Değerlendirilmesi. KSÜ Tarım ve Doğa Derg 22(4): 650-658. DOI: 10.18016/ksutarimdoga.vi.526634 


\section{GİRIŞ}

L-karnitin ( $\mathrm{Y}$-trimetilamino-6-hidroksibutirik asit) yüksek oranda hayvansal dokularda bulunan ve sitoplazmadan mitokondri matriksine transfer edilecek uzun zincirli yağ asitlerinin iç mitokondrial membrandan geçişinde görev alan amino asit türevi olarak tanımlanmaktadır (Kopec ve Fritz, 1973; Mroczkowska ve ark., 1997; Shug ve ark., 1982). Hidrofilik yapıda ve düşük molekül ağırlığına sahip olan l-karnitin, ilk kez kas dokudan izole edildiğinden dolayı "carnis" (Gulewitsch ve Krimberg 1905) kelimesinden köken alınarak adlandırılmıştır (Surai 2015). Carter ve ark. (1952), Tenebrio molitor 'da lkarnitini, vitamin benzeri bir aktivite gösterdiği ve organizmanın büyümesini teşvik ettiği için vitamin BT olarak adlandırmıştır (Çitil, 2002). Hücrenin enerji üretim metabolizmasında, uzun zincirli serbest yağ asitlerinin beta oksidasyonu için kristadan matrikse geçiş için gerekli olan kofaktör olarak görev almaktadır. L-karnitin beta oksidasyonu hızını artırarak asetil CoA miktarının da artmasını sağlamanın yanısıra, potansiyel toksik asetil CoA metabolitlerini engellemek suretiyle asetil $\mathrm{CoA} / \mathrm{CoA}$ oranının düzenlenmesine yardımcı olmaktadır. Asetil $\mathrm{CoA} / \mathrm{CoA}$ oranının düzenlenmesi, krebs döngüsü, glukoneogenez, üre döngüsü ve yağ asitlerinin oksidasyonunda görev alan çok sayıda mitokondriyal enzim aktivitesinin düzenlenmesinde önemlidir (Lehninger ve ark., 1993; Chen ve ark., 1998; Monograph, 2005). Karnitin temel olarak, sitozolden mitokondriyal matrikse uzun zincirli yağ asitlerinin taşınımı, krebs döngüsü, asetil-karnitin olarak enerjinin depolanması, membran yapısının korunması ve apoptozis inhibisyonundan sorumlu olmaktadır (Vaz ve Wanders 2002; Ribas ve ark., 2014).

Düşük maliyeti, hızlı ve güvenilir sonuçları ile organizma grubunun incelemeye kısa sürede yanıt vermesi gibi avantajları dolayısıyla, bitki genotoksisite testleri mutasyonları da kapsayan kromozomal anormalliklerini değerlendirmede biyolojik test yöntemi olarak kullanılmaktadır (Grant, 1978, 1999). Bitkiler diğer organizmalara göre düşük kromozom sayısı ve büyük kromozom yapısına sahip olma avantajlarından dolayı da (Kihlman, 1977; Grant, 1994; Leme ve ark., 2009) radyasyon, pestisit, çevresel kirleticiler (Baderna ve ark., 2011) ve mutajenik kimyasalların sebep olduğu genetik değişimlerin erken keşfedilmesinde önemli bir siklıkta kullanılmaktadırlar (Sharma ve Paneerselvan 1990).

Allium cepa L. (soğan), kimyasal komponentler, çevresel kirleticiler ya da ksenobiyotiklerin laboratuvar ortamında kök büyümesi, mitotik indeks, ve hücre döngüsü boyunca meydana gelen sitogenotoksik durumlar için (Gadano ve ark., 2002) hücre proliferasyonunun kinetik özelliklerine sahip kararlı kromozom sayısına sahip olma gibi etkilerinin çalışılmasında en sık kullanılan test sistemidir (Leme ve Marin-Morales, 2009; Barberio ve ark., 2011; Sharma ve Vig, 2012; Firbas ve Amon, 2013; Pathiratne ve ark., 2015). Ayrica, kromozom anormallikleri, ploidi tespiti, kardeş kromatid değişimleri (Kumar ve ark., 2011) nuklear değişimler (Nas) ve meristematik hücrelerdeki mikronükleus (MNi) oluşumu gibi DNA'da meydana gelen hasarı (Trushin ve ark., 2013; Nefic ve ark., 2013) tespit etmek için 1920'li yıllardan bu yana kullanılmaktadır. Bunun yanı sıra $A$. cepa kök ucu testi, mutajenik etkilerin görüntülenmesinde oldukça etkili bir biyotest olarak Birleşmiş Milletler Çevre Programı (UNEP) ile Uluslararası Kimyasal Güvenlik Programı (IPCS) tarafından 1991 yllında sertifikalandırılmıştır (Cabrera ve Rodriguez, 1999). A. cepa gibi in vivo bitki test sistemleri kullanılarak yapılan sitotoksisite testleri, in vitro hayvansal organizma testleri ile çalışan birçok araştırmacı tarafından onaylanmıştır ve elde edilen sonuçların benzer olduğunu ve insan sağlığı açısından önemli bilgiler sağladığını belirtmişler (Vicentini ve ark., 2001; Teixeira ve ark., 2003).

$\mathrm{Bu}$ çalışma, piyasada farklı dozlarda (100, 250, 500, $750,1000,1250 \mathrm{mg}$ ) satılan ve enerji üretim mekanizmasındaki rolünden dolayı diyetlerde gıda takviyesi olarak sıklıkla kullanılan l-karnitinin, hücre döngüsü basamakları boyunca mitotik indeks ve kromozom davranışları üzerine etkilerine dair genotoksik hasarın tespit edilmesi amaçlanmıştır.

\section{MATERYAL ve METOT}

\section{Deneylerde Kullanılan Tohumlar ve L-Karnitin Çözeltilerinin Hazırlanması}

Deneylerde, yıl içerisinde sıklıkla bulunabilen Allium cepa L. Tohumları sertifikalı bir işletmeden satın alınmıştır. Çalışmada, kullanılan L-karnitin miktarları piyasada ticari olarak satılan miktarlar değerlendirilerek 100, 250, 500, 750, 1000 ve 1250 $\mathrm{mg} / \mathrm{L}$ konsantrasyonların saf suda çözdürülüp litreye tamamlanması ile hazırlanmıştır. Kontrol grubu olarak ise saf su kullanılmıştır (0 mg/L l-karnitin).

\section{Tohumların Cimlendirilmesi}

Öncelikle yeterli sayıda, dolgun görünüşlü, sağlam ve birbirine benzer büyüklükteki soğan tohumları seçilerek içerisinde belirli miktarlarda l-karnitin konsantrasyonları bulunan beherlerde 24 saat süreyle bekletilmiştir. 24 saatlik sürenin sonunda tohumlar süzülmüş ve saf su ile yıkanıp kurutulduktan sonra içerisinde $7 \mathrm{ml}$ saf su bulunan petri kutularına, her petride 25 tohum olacak şekilde üç tekrarlı ekim yapılarak $20 \quad{ }^{\circ}$ C'ye ayarlı etüvde 7 gün boyunca çimlendirilmiştir (Şekil 1). 

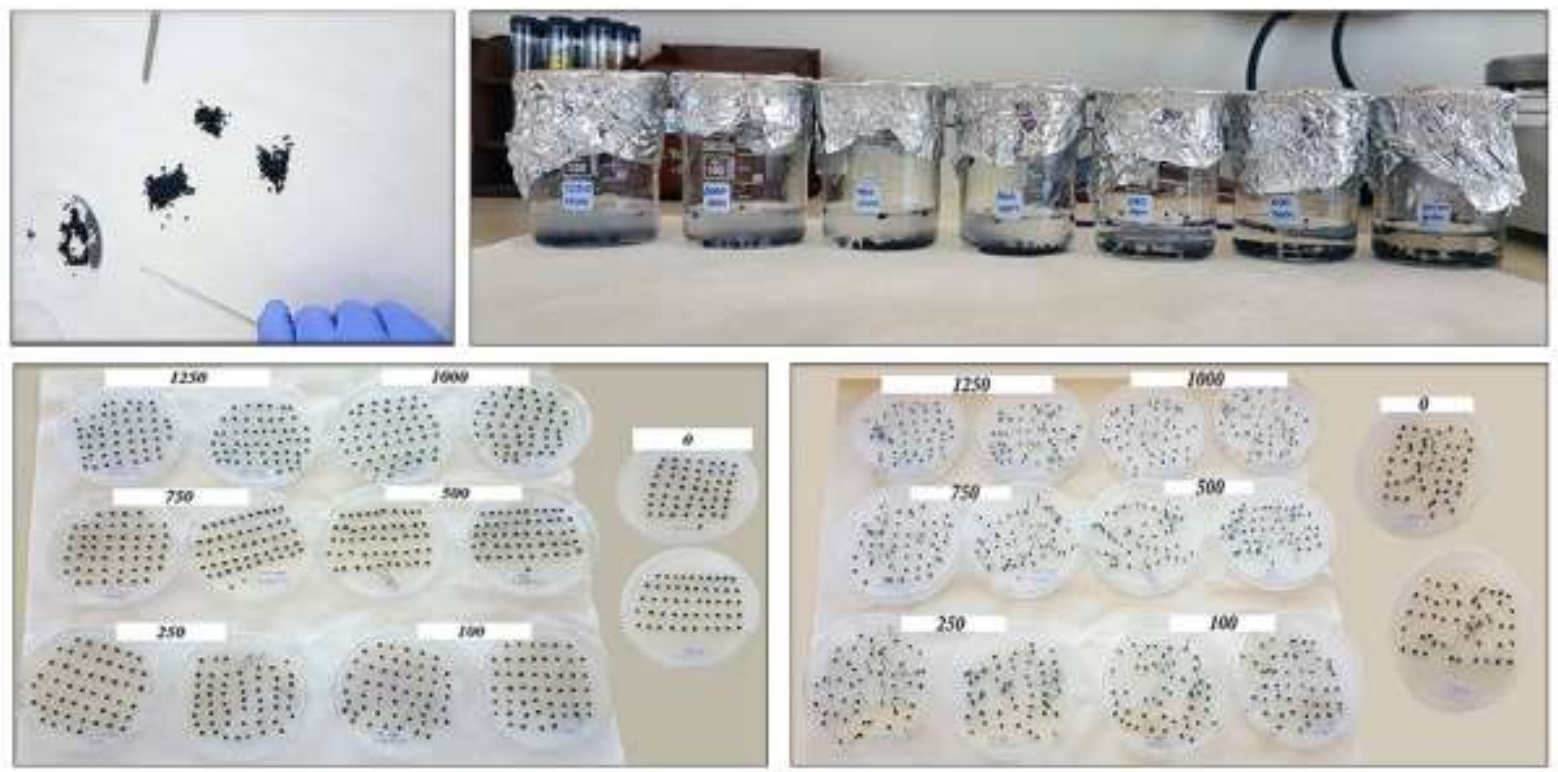

Şekil 1. Farklı konsantrasyonlarda L-karnitinin A. cepa L. tohumlarında 24 saat süre ile ön uygulamaya tabi tutulması ve petri kaplarında saf su ortamında çimlendirilmesi

Kök Uçlarının Elde Edilmesi ve Sitogenetik Analizler

Her bir uygulama grubuna ait çimlenmiş tohumlardan kök uçları 0,5 - $1 \mathrm{~cm}$ uzunluğa ulaşanlar kesilerek mitotik bölünmenin durdurulması amacıyla ilk işlem çözeltisi olarak paradiklorobenzen çözeltisinde 4 saat süreyle bekletildikten sonra fiksasyon işlemi için Carnoy solüsyonunda (1:3) 24 saat bekletilmiştir. Tespit işleminden sonra kök uçları hücre duvarını parçalamak amacıyla $1 \mathrm{~N} \mathrm{HCl}$ içerisinde $60^{\circ} \mathrm{C}$ 'ye ayarlı etüvde $9 \mathrm{dk}$ süreyle hidroliz edilmiştir. Hidrolizin ardından, mitotik indeks ve kromozomal anormalliklerin en iyi şekilde tespit edilebilmesini sağlamak için yapısında kristal halde fuksin bazik bulunan Feulgen boyası yardımıyla 1 saat boyunca boyanmıştır (Fox, 1969).

\section{Mitotik Indeks ve Kromozom Anormalliklerinin Belirlenmesi}

Her bir preparatta tek bir kök ucu meristemi olacak şekilde hazırlanan toplam üç preparat, mikroskopta 100X büyütmede incelenmiş ve her konsantrasyon için hazırlanan üç preparata ait 3000 hücre (her kök ucu için 1000 hücre) sayılmıştır. Daha sonra, mitoz bölünmede sayılan hücreler için mitotik indeks değeri;

Mitotik İndeks $=\frac{\text { Mitozdaki Hücre Sayısı }}{\text { Toplam Hücre Sayısı }}$

(Sehgal ve ark. 2006) formülü ile belirlenmiştir.

Faz indeksleri;

$I_{f a z}=$ (Faza ait hücre sayısı)/

(toplam bölünen hücre sayısı) (Ivanova ve ark. 2003) formülü kullanılarak değerlendirilmiştir.

Preparatların mikroskobik incelemeleri sırasında sayılan kromozom anormallikleri ise;

Kromozom Aberasyon İndeksi $\left(I_{K A}\right)=\frac{\text { Anormal Hücre Sayısı }}{\text { Mitozdaki Hücre Sayısı }}$

formülü ile belirlenmiştir.

Kromozom anormalliklerine ait resimler Carl Zeiss AxioScope marka trinokuler araştırma mikroskobunda 100X büyütme ile ve Canon 650D model fotoğraf makinesi ile çekilmiştir.

\section{İstatistiksel Değerlendirme}

L-karnitin uygulanmamış, saf suda yetiştirilmiş kontrol grubu soğan bitkileri ile farklı l-karnitin dozları ön uygulanmış soğan bitkilerinin karşılaştırılması için SPSS 22 (IBM, 2013) programında ANOVA testi kullanılmıştır. Her grup arasındaki farklılıkları tanımlamak için Nonparametric Kruskal-Wallis testi ve Duncan's multiple range testi $\mathrm{p} \leq 0.05$ (Duncan, 1955) oranındaki farklılık esas alınarak değerlendirilmiştir.

\section{BULGULAR ve TARTIŞMA}

L-Karnitin Ön Uygulamasinin A. cepa L. Meristematik Hücrelerinde Mitotik İndeks Üzerine Etkileri

Farklı dozlardaki (1250, 1000, 750, 500, 250, $100 \mathrm{mg} / \mathrm{L})$ l-karnitin ön uygulamasına tabi tutulmuş $A$. cepa kök meristematik hücrelerinde l-karnitinin hücre bölünmesi üzerine muhtemel etkileri Çizelge 1'de verilmiştir. Sitogenetik analizler, DNA seviyesinde türe özgü etkilerin belirlenmesinde kullanılan en etkili yöntemlerden biri olarak gösterilmektedir. Araştırmacılara mutagenez sonucunda meydana gelen sitogenetik değişimleri inceleme imkânı sunmaktadır. 
Çizelge 1. Farklı konsantrasyonlarda $(100,250,500,750,1000,1250 \mathrm{mg} / \mathrm{L})$ L-karnitin ön uygulamasina tabi tutulmuş ve L-karnitin uygulanmamış (0 mg/L l-karnitin) Allium cepa L. kök meristematik hücrelerinde mitotik indeks $(M I)$ ve faz indeksi $\left(I_{p}, I_{M}, I_{A}, I_{T}\right)$ değerleri

\begin{tabular}{|c|c|c|c|c|c|}
\hline $\begin{array}{l}L \text {-Karnitin } \\
\text { On uygulama }(m g / L)\end{array}$ & Mitotik Indeks (MI) & Profaz Indeksi $\left(I_{p}\right)$ & $\begin{array}{l}\text { Metafaz } \\
\text { Indeksi (IM })\end{array}$ & $\begin{array}{l}\text { Anafaz } \\
\dot{I n d e k s i}_{\left(I_{A}\right)}\end{array}$ & $\begin{array}{l}\text { Telofaz } \\
\text { Indeksi }\left(I_{T}\right)\end{array}$ \\
\hline Kontrol & ${ }^{*} 0.20 \pm 0.05^{c}$ & $0.69 \pm 0.01^{b}$ & $0.12 \pm 0.02^{\mathrm{ab}}$ & $0.07 \pm 0.01^{b}$ & $0.02 \pm 0.02^{\mathrm{ab}}$ \\
\hline 1250 & $0.22 \pm 0.03^{\mathrm{cd}}$ & $0.39 \pm 0.08^{\mathrm{a}}$ & $0.05 \pm 0.03^{a}$ & $0.03 \pm 0.02^{\mathrm{ab}}$ & $0.03 \pm 0.01^{\mathrm{ab}}$ \\
\hline 1000 & $0.25 \pm 0.02^{\mathrm{d}}$ & $0.43 \pm 0.03^{\mathrm{a}}$ & $0.06 \pm 0.01^{\mathrm{a}}$ & $0.02 \pm 0.00^{\mathrm{ab}}$ & $0.04 \pm 0.01^{\mathrm{ab}}$ \\
\hline 750 & $0.15 \pm 0.01^{b}$ & $0.51 \pm 0.01^{\mathrm{a}}$ & $0.12 \pm 0.03^{\mathrm{ab}}$ & $0.07 \pm 0.06^{\mathrm{b}}$ & $0.06 \pm 0.00^{b}$ \\
\hline 500 & $0.11 \pm 0.03^{a}$ & $0.42 \pm 0.02^{\mathrm{a}}$ & $0.12 \pm 0.02^{\mathrm{ab}}$ & $0.03 \pm 0.06^{\mathrm{ab}}$ & $0.03 \pm 0.06^{\mathrm{ab}}$ \\
\hline 250 & $0.21 \pm 0.01^{\mathrm{c}}$ & $0.46 \pm 0.09^{\mathrm{a}}$ & $0.06 \pm 0.04^{b}$ & $0.01 \pm 0.01^{\mathrm{ab}}$ & $0.04 \pm 0.03^{\mathrm{ab}}$ \\
\hline 100 & $0.20 \pm 0.02^{\mathrm{c}}$ & $0.49 \pm 0.01^{\mathrm{a}}$ & $0.33 \pm 0.02^{\mathrm{c}}$ & $0.00 \pm 0.00^{\mathrm{a}}$ & $0.00 \pm 0.00^{\mathrm{a}}$ \\
\hline
\end{tabular}

*Her bir parametre sütununda aynı harfle gösterilen değerler arasındaki fark $(\mathrm{p}<0.05)$ düzeyinde önemsizdir.

\pm Standart sapma

Mitotik indeks, hücre döngüsünde mitotik hücrelerin proliferasyonunu (M fazı) ölçmeye yardımcı olan bir sitogenetik parametredir ve mitotik indeksin inhibisyonu hücre ölümü olarak değerlendirilmektedir (Rojas ve ark. 1993; Gadano ve ark. 2002). Yapilan literatür taramasında bitkisel organizmalarda $\mathrm{l}^{-}$ karnitinin mitotik indeks üzerine etkilerine dair herhangi bir çalışmaya rastlanmamıştır. Buna göre, elde edilen bulgular doğrultusunda $1250(0.22)$ ve 1000 mg (0.25) l-karnitin ön uygulaması kontrol grubu soğan hücrelerine (0.20) oranla istatistik açıdan önemlidir ve hücre bölünmesini teşvik etmişlerdir. Genel olarak, $500 \quad(0.11)$ ve $750 \quad(0.15) \quad$ mg'llk konsantrasyonların mitotik aktiviteyi baskıladığ 100

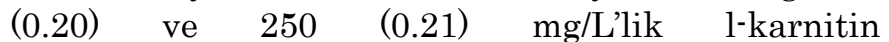
konsantrasyonlarının ise kontrol grubuna istatistik açıdan eşdeğer aktivite gösterdiği tespit edilmiştir (Çizelge 1). Buna ek olarak, $M$ fazına geçen hücrelerin profaz safhasında yoğunlaştığı belirlenmiştir. Ancak, profaz indeksi oranı en yüksek kontrol grubu (0.69) soğan hücrelerinde belirlenmiştir. Kontrol grubu ile farklı dozlarda l-karnitin uygulanmış soğan kök ucu meristematik hücrelerinde istatistik olarak anlamlı fark yalnizca profaz safhasinda kontrol grubunda ortaya çıkarken metafaz safhasında $100 \mathrm{mg}$ l-karnitin uygulaması, anafaz ve telofaz safhasinda ise $750 \mathrm{mg} \mathrm{l-}$ karnitin uygulamasında en yüksek ve istatistik olarak anlamlı indeks değerlerine rastlanmıştır $(p \leq 0.05)$ (Çizelge 1). L-karnitin ön uygulamasında doz artışına paralel olarak, mitotik indeks 750 ve 500 mg'llk dozlarda önemli ölçüde azalmıştır. En yüksek mitotik indeks değerini gösteren 1000 mg'llk l-karnitin ön uygulaması hücre bölünmesini ve mitotik aktiviteyi teşvik edici eşik doz olarak bulunmuştur. $1250 \mathrm{mg} \mathrm{g}^{\prime} \mathrm{l} \mathrm{k}$ l-karnitin konsantrasyonu kontrol grubuna göre hücre döngüsünü teşvik etse de 1000 mg'llk konsantrasyon kadar üzerinde bir olumlu etki gösterememiştir. Diğer bir değişle, $1000 \mathrm{mg} \mathrm{l-karnitin} \mathrm{ön} \mathrm{uygulaması} \mathrm{soğan}$ kök meristemlerinde mitotik döngüyü teşvik edici etkisinden dolayı bitki büyümesini düzenleyici bir bitki besin elementi olarak önerilebilir. Bitkisel organizmalar dair literatürde herhangi bir çalışmaya rastlanmamakla birlikte hayvansal organizmalarda ekzojen l-karnitin alımının büyümeyi teşvik ettiği, bağışılklık sistemini güçlendirdiği ve antioksidan etkisinden dolayı kümes hayvanlarında stresli koşullara direnç sağladığı belirtilmektedir (Arslan 2006; Golzar Adabi ve ark., 2011). Ayrica, l-karnitinin hücresel koruyucu etkisinin de olduğunu göstermektedir (Surai, 2015). Ayrıca, in vitro çalışmalar, hayvan hücrelerinde karnitinin yüksek konsantrasyonlarının (10, 75, $80 \mathrm{mM}$ ) (Reznick ve ark., 1992; Di Giacomo ve ark., 1993; Vanella ve ark., 2000) düşük konsantrasyonlarına (1, 3, 5 mM) (Vanella ve ark., 2000) oranla serbest radikal salınımında daha etkili olduğunu belirtmiştir. Yapılan çalışma sonucunda elde edilen bulgularımız da $100 \mathrm{mg} / \mathrm{L}^{\prime}$ lik lkarnitin konsantrasyonuna göre 1250 ve 1000 mg/L'lik konsantrasyonların tohum çimlenmesi, kök büyümesinin teşviki ve mitotik aktivitenin teşvik edilmesinde oldukça başarılı olduğu ortaya konulmuştur.

L-Karnitin Ön Uygulamasinin $A$. cepa L. Meristematik Hücrelerinde Genotoksik Etkileri

Farklı dozlardaki (1250, 1000, 750, 500, 250, 100 mg/L) l-karnitin ön uygulamasına tabi tutulmuş $A$. cepa kök meristematik hücrelerinde l-karnitinin kromozom yapısı ve nükleus üzerine etkileri Çizelge 2'de kromozom aberasyonları olarak verilmiştir. L-karnitin uygulanmamış kontrol grubu (0 mg/L l-karnitin) soğan hücrelerinde yapılan sayımlar sonucunda mitotik hücrelerin tümü normal kromozom yapısında gözlenmiş ve herhangi bir kromozomal aberasyon ile karşılaşılmamış ve soğan mitotik metafaz hücrelerinin kromozom sayısı $2 \mathrm{n}=2 \mathrm{x}=16$ olarak belirlenmiştir (Çizelge 2, Şekil 2). Allium cepa biyotesti, muhtemel toksik etkenlerin kök meristematik hücrelerinde oluşan mitotik fazdaki kromozomal anormalliklerinin (Maluszynska ve Juchimiuk 2005; Levan, 1938; Campos ve ark., 2009; Leme ve Marin-Morales, 2009) ortaya konulmasında, soğan bitkisinin az sayıda monosentrik kromozom sayısına sahip olması $(2 \mathrm{n}=16)$, kromozomların iyi boyanabilmesi (Fiskesjö, 1995) ve 
bölünen hücre sayısı yüzdesinin yüksek olması gibi avantajlarından dolayı sitotoksisite testleri için uygun bir kaynak olarak sıklıkla kullanılmaktadır.

Aynı şekilde bu çalışmada, farklı konsantrasyonlardaki l-karnitin ön uygulamasına tabi tutulmuş soğan hücrelerinde farklı tipte kromozom aberasyonları gözlenmiştir (Çizelge 2, Şekil 3-5).

Ancak, konsantrasyon artışına bağlı olarak kromozom aberasyon indeksleri $\left(I_{K A}\right)$ arasinda rakamsal olarak farklılıklar görülse de $500 \mathrm{mg} / \mathrm{L}$ 'lik l-karnitin konsantrasyonu hariç diğer tüm konsantrasyonlar arasında istatistik açıdan önemli $(\mathrm{p} \leq 0.05)$ bir fark gözlenmemiştir. Kromozom aberasyon indeksi en yüksek mitotik indeks frekansına sahip $1000 \mathrm{mg} / \mathrm{L}$ 'lik konsantrasyonda 0.08 iken en düşük mitotik indeks frekansına sahip olan $500 \mathrm{mg} / \mathrm{L}$ 'lik konsantrasyonda 0.20 olarak saptanmıştır. Buradan, $500 \mathrm{mg} / \mathrm{L}$ 'lik lkarnitin dozunun soğan kök ucu meristematik hücrelerinde mitodepsesif bir etki oluşturarak kromozom yapısı ve fonksiyonunda değişikliklere sebep olacak genotoksik etkiye sebep olduğu bulunmuştur.

Çizelge 2. Farklı konsantrasyonlarda (100, 250, 500, 750, 1000, $1250 \mathrm{mg} / \mathrm{L})$ L-karnitin ön uygulamasına tabi tutulmuş ve Lkarnitin uygulanmamış (0 mg/L l-karnitin) Allium cepa L. kök meristematik hücrelerinde total kromozom aberasyon indeksi $\left(I_{G}\right)$ ve farklı tipteki aberasyon indeksi değerleri

\begin{tabular}{|c|c|c|c|c|c|c|c|c|}
\hline $\begin{array}{l}\text { L-carnitine } \\
\text { Ön uygulama } \\
\text { (mg/L) }\end{array}$ & $\begin{array}{l}\text { Kromozom } \\
\text { Aberasyon } \\
\text { İndeksi (IKA) }\end{array}$ & $\begin{array}{l}\text { Düzensiz } \\
\text { Profaz }\end{array}$ & $\begin{array}{l}\text { Yapıskan } \\
\text { Krozomozom }\end{array}$ & Micronukleus & $\begin{array}{l}\text { Yanliş } \\
\text { Kutuplaşma }\end{array}$ & $\begin{array}{l}\text { Anafaz } \\
\text { /Telofaz } \\
\text { Köprüsü }\end{array}$ & $\begin{array}{l}\text { Vagrant } \\
\text { Kromozom }\end{array}$ & $\begin{array}{l}\text { Multinuklear } \\
\text { Hücre }\end{array}$ \\
\hline Kontrol & $* 0.00 \pm 0.00^{a}$ & $0.00 \pm 0.00^{\mathrm{a}}$ & $0.00 \pm 0.00^{\mathrm{a}}$ & $0.00 \pm 0.00^{\mathrm{a}}$ & $0.00 \pm 0.00^{\mathrm{a}}$ & $0.00 \pm 0.00^{\mathrm{a}}$ & $0.00 \pm 0.00^{\mathrm{a}}$ & $0.00 \pm 0.00^{\mathrm{a}}$ \\
\hline 1250 & $0.05 \pm 0.01^{\mathrm{ab}}$ & $0.69 \pm 0.02^{\mathrm{c}}$ & $0.00 \pm 0.00^{\mathrm{a}}$ & $0.00 \pm 0.00^{\mathrm{a}}$ & $0.00 \pm 0.00^{\mathrm{a}}$ & $0.13 \pm 0.01^{\mathrm{de}}$ & $0.13 \pm 0.01^{\mathrm{ab}}$ & $0.00 \pm 0.00^{\mathrm{a}}$ \\
\hline 1000 & $0.08 \pm 0.01^{\mathrm{ab}}$ & $0.26 \pm 0.06^{\mathrm{ab}}$ & $0.00 \pm 0.00^{\mathrm{a}}$ & $0.00 \pm 0.00^{\mathrm{a}}$ & $0.29 \pm 0.21^{\mathrm{bc}}$ & $0.20 \pm 0.01^{\mathrm{e}}$ & $0.17 \pm 0.04^{\mathrm{ab}}$ & $0.16 \pm 0.01^{b}$ \\
\hline 750 & $0.13 \pm 0.02^{\mathrm{ab}}$ & $0.18 \pm 0.01^{\mathrm{a}}$ & $0.00 \pm 0.00^{\mathrm{a}}$ & $0.00 \pm 0.00^{\mathrm{a}}$ & $0.39 \pm 0.01^{c}$ & $0.17 \pm 0.06^{\mathrm{de}}$ & $0.24 \pm 0.31^{\mathrm{ab}}$ & $0.32 \pm 0.02^{\mathrm{c}}$ \\
\hline 500 & $0.20 \pm 0.26^{b}$ & $0.47 \pm 0.32^{\mathrm{bc}}$ & $0.07 \pm 0.04^{b}$ & $0.00 \pm 0.00^{\mathrm{a}}$ & $0.00 \pm 0.00^{\mathrm{a}}$ & $0.04 \pm 0.03^{\mathrm{ab}}$ & $0.11 \pm 0.03^{\mathrm{a}}$ & $0.00 \pm 0.00^{\mathrm{a}}$ \\
\hline 250 & $0.07 \pm 0.02^{\mathrm{ab}}$ & $0.13 \pm 0.01^{\mathrm{a}}$ & $0.01 \pm 0.01^{\mathrm{a}}$ & $0.06 \pm 0.05^{b}$ & $0.10 \pm 0.01^{\mathrm{ab}}$ & $0.11 \pm 0.05^{\mathrm{bcd}}$ & $0.06 \pm 0.05^{\mathrm{a}}$ & $0.43 \pm 0.03^{c}$ \\
\hline 100 & $0.08 \pm 0.02^{\mathrm{ab}}$ & $0.06 \pm 0.07^{\mathrm{a}}$ & $0.01 \pm 0.01^{\mathrm{a}}$ & $0.00 \pm 0.00^{a}$ & $0.50 \pm 0.25^{c}$ & $0.07 \pm 0.04^{\mathrm{abc}}$ & $0.37 \pm 0.13^{b}$ & $0.00 \pm 0.00^{\mathrm{a}}$ \\
\hline Kontrol & $* 0.00 \pm 0.00^{\mathrm{a}}$ & $0.00 \pm 0.00^{\mathrm{a}}$ & $0.00 \pm 0.00^{\mathrm{a}}$ & $0.00 \pm 0.00^{\mathrm{a}}$ & $0.00 \pm 0.00^{\mathrm{a}}$ & $0.00 \pm 0.00^{\mathrm{a}}$ & $0.00 \pm 0.00^{\mathrm{a}}$ & $0.00 \pm 0.00^{\mathrm{a}}$ \\
\hline
\end{tabular}

*Her bir parametre sütununda aynı harfle gösterilen değerler arasındaki fark $(\mathrm{p}<0,05)$ düzeyinde önemsizdir.

\pm Standart sapma
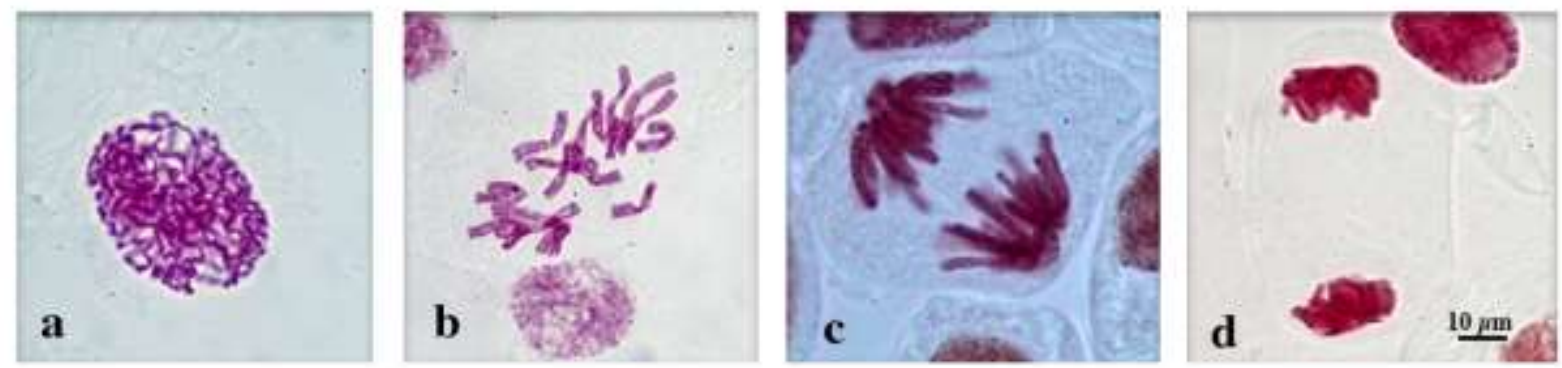

Şekil 2. L-karnitin ön uygulamasına tabi tutulmamış kontrol grubu A. cepa L. kök meristematik hücrelerinde gözlenen normal mitotik fazlar a) Profaz b) Metafaz $(2 n=16)$ c) Anafaz d) Telofaz
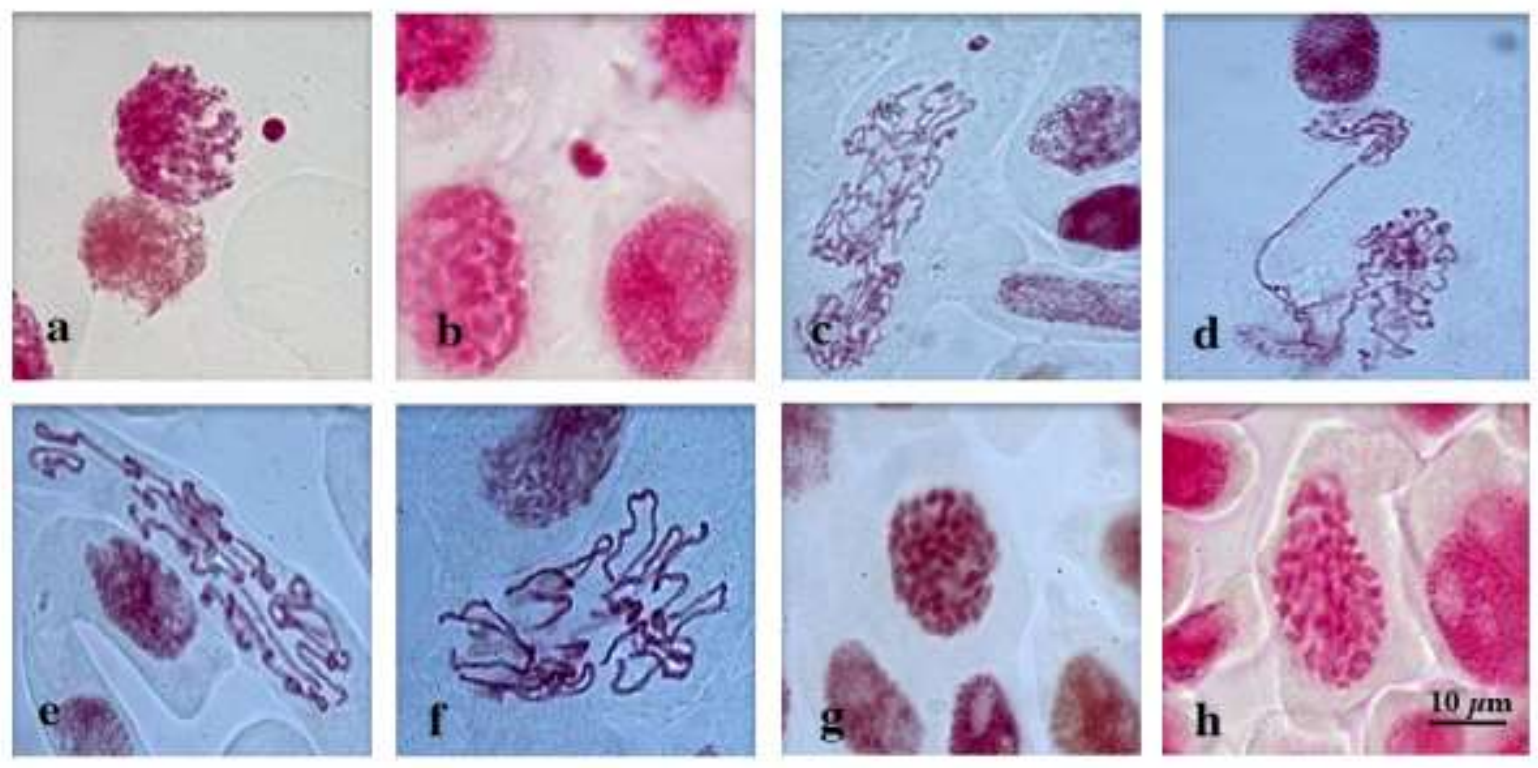

Şekil 3. Farklı konsantrasyonlarda L-karnitin ön uygulamasına tabi tutulmuş $A$. cepa L. kök meristematik hücrelerinde, profaz safhasında gözlenen kromozom aberasyonları a -c) mikronukleus oluşumu; d-f) Düzensiz profaz; g, h) granulasyon Skala: $10 \mu \mathrm{m}$ 

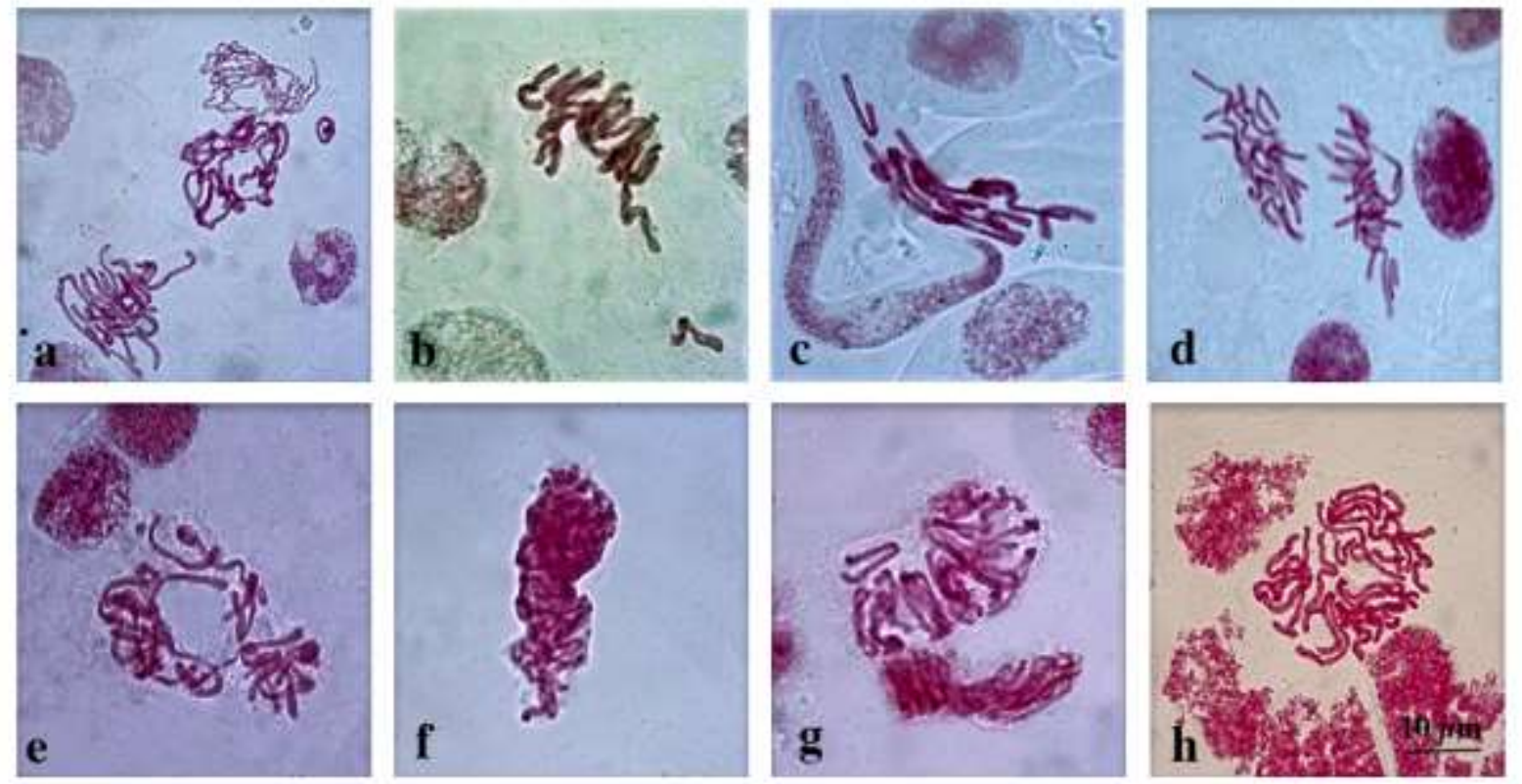

Şekil 4. Farklı konsantrasyonlarda L-karnitin ön uygulamasına tabi tutulmuş $A$. cepa L. kök meristematik hücrelerinde, metafaz safhasında gözlenen kromozom aberasyonları a) Halka kromozom yapısı b, c) Düzensiz metafaz; d) Poliploidi; e) C- mitoz f) Yapışık kromozom; g, h) Sarmallanamamış kromozom yapısı. Bar: $10 \mu \mathrm{m}$
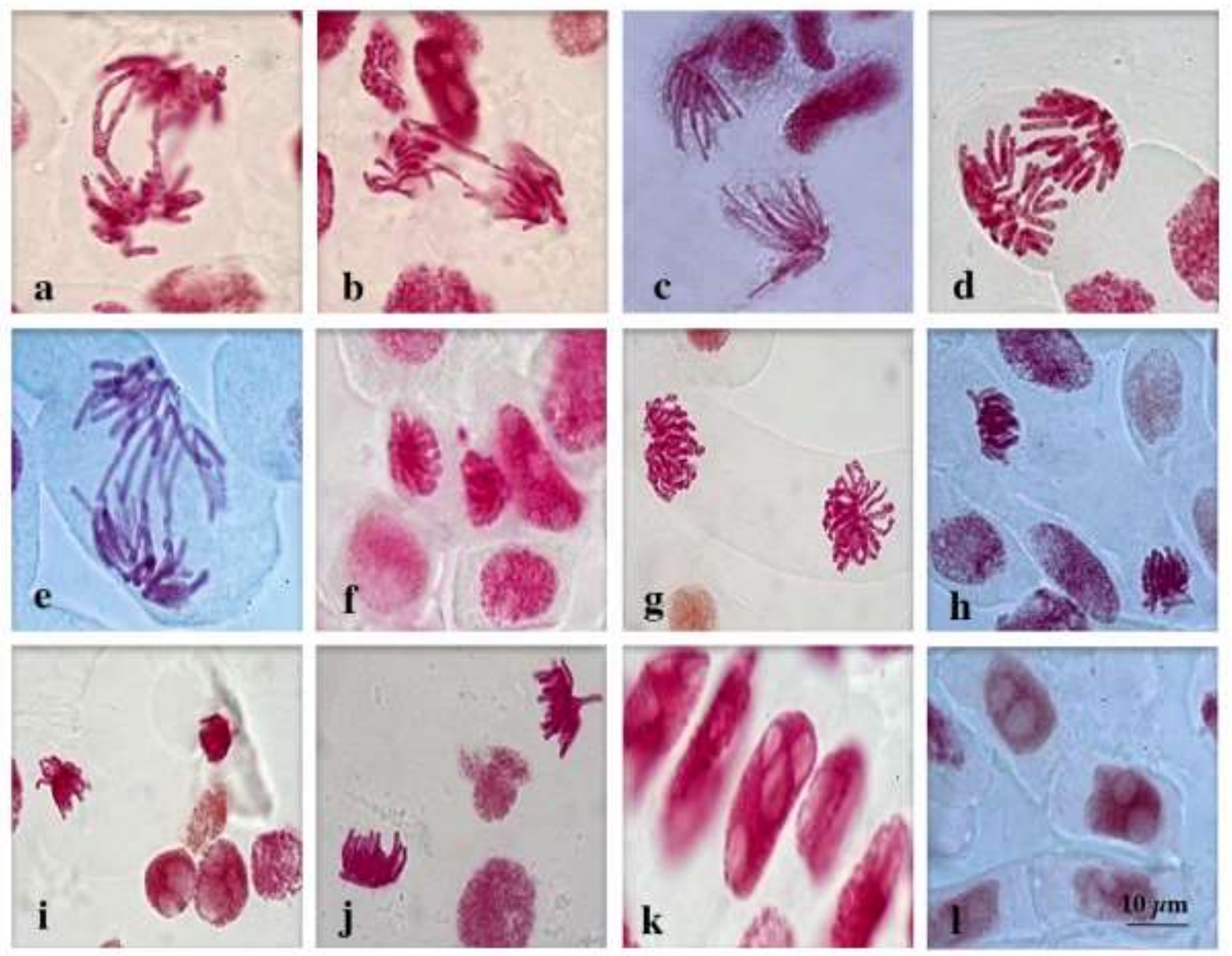

Şekil 5. Farklı konsantrasyonlarda L-karnitin ön uygulamasına tabi tutulmuş $A$. cepa L. kök meristematik hücrelerinde, anafaz ve telofaz safhasında gözlenen kromozom aberasyonları a, b) Köprü oluşumu ve vagrant kromozomlar; c) Fragmentasyon; d) Kutupsuz anafaz; e) Anafaz Köprüsü f) Mikronükleus oluşumu g) Kutupsuz telofaz; h-j) Yanlış kutuplaşma; k, l) Multinuklear hücre. Bar: $10 \mu \mathrm{m}$ 
Bitkiye büyüme gelişme ya da toksisite testleri için dışarıdan verilen maddeler bitkide ilk etapta stres olarak algılanmaktadır ve bu etki uygulanan konsantrasyona ya da doza bağlı olarak DNA sentezinin baskılanması (Mercykutty ve Stephen 1980; Schulze ve ark., 1986) ya da mitoz bölünmenin engellenmesi (Akinboro ve Bakare 2007) şeklinde mitodepresif etkilere sebep olabilmektedir. Dışarıdan bitkiye verilen her maddenin içeriği itibariyle, kromozom yapısı üzerinde farklı seviyelerde klastojenik yanıtlar ortaya çıkarması uygulanan konsantrasyon ve türe bağlı olarak farklılık gösterebilmektedir (Leme and Marin-Morales 2009).

Çalışmamız, literatürde l-karnitinin soğan kök ucu meristemleri üzerine klastojenik etkilerin belirlenmesine dair yapılan ilk çalışmadır. Bunun yanı sıra, yüksek konsantrasyonlarda uygulanan 1karnitinin ise hem mitotik aktiviteyi teşvik ettiği hem de DNA'da ya da kromatidlerde meydana gelebilecek mutasyonel hasarı indirgemek suretiyle kromozom stabilitesini korumaya yardımcı olduğu ortaya konulmuştur.

Benzer olarak, hayvan hücrelerinde, oksidatif stresin negatif etkilerini hafifletmek amacıyla kullanılan 1karnitinin kromozom aberasyonları ve DNA hasarında önemli oranda azalmalar sağladiğı (Santoro ve ark., 2005; Zakzok ve ark., 2018), tümör büyümesini inhibe ettiği (Ricciardi ve ark., 2015; Melone ve ark., 2018) ve kanser hücrelerinin ölümünü teşvik ettiği (Pacilli ve ark., 2013) ortaya konulmuştur. Yine, çalışmamız stressiz koşullar altında bitkisel hücrelerde lkarnitinin etkilerine dair yapılan ilk çalışma olmakla birlikte l-karnitinin hücre proliferasyonunu koruduğuna dair yapılan çalışmalar ile örtüşmektedir. Buradan, kontrol grubu ile l-karnitin ön uygulanmış soğan hücreleri karşılaştırıldığında, bitkiye dışarıdan verilen bir etken maddenin ilk etapta bitki savunma mekanizması gereği stres olarak algılandığından dolayı, l-karnitin ön uygulamasının hücre döngüsü üzerinde mitodepresif bir etkiye sahip olması çalışmanın bulgularının literatür ile uyumlu olduğunu göstermektedir. Kromozom aberasyonları içerisinde en sık görüntülenen aberasyon tipleri düzensiz profaz, anafaz ve telofaz köprüleri ile kalgin kromozomlar ve çift nukleuslu hücreler olarak belirlenmiştir (Şekil 3). Yine, yapışık kromozom aberasyonu (Şekil 4f) yalnızca $500 \mathrm{mg} / \mathrm{L}$ 'lik l-karnitin ön uygulamasına ait hücrelerde görüntülenirken mikronukleus (Şekil 3a-c, Şekil 5f) oluşumuna sadece $250 \quad \mathrm{mg} / \mathrm{L}$ 'lik l-karnitin konsantrasyonda gözlenmiştir. Buna ek olarak, anafaz ve telofaz safhasinda rastlanan kutuplara çekilme sırasında ortaya çıkan düzensiz ya da yanlış kutuplaşma (Şekil 5h-j) durumuna 750 ve $500 \mathrm{mg} / \mathrm{L}$ 'lik l-karnitin konsantrasyonlarında rastlanamamıştır. Stressiz koşullar altında ekzojen l-karnitin uygulamasının etkilerine dair literatürde herhangi bir çalışma olmamasına rağmen stresli koşullar altında l- karnitin alımının muhtemel etkilerine dair çok sayıda çalışma mevcuttur (Franken ve Bauer, 2010; Angelidis ve Smith, 2003; Ribas ve ark., 2014). Bu nedenle, çalışmamız farklı dozlarda ekzojen l-karnitin alımının hücre bölünmesi ve kromozom davranışları üzerine etkilerinin irdelenmesine dair literatürdeki ilk çalışmadır.

\section{SONUÇ ve ÖNERİLER}

Özellikle diyetlerde, metabolizmada enerji üretim mekanizması ile ilişkili olan ve yağ yakımına yardımcı olduğu gerekçesi ile gıda takviyesi olarak alınan 1karnitinin ticari olarak satılan farklı konsatrasyonlarının insan hücreleri üzerine olması muhtemel sitotoksik etkilerinin Allium cepa kök ucu testi ile belirlenmesine dair yürütülen çalışmada lkarnitinin yüksek konsantrasyonlarının hücresel koruyucu bir role sahip oldukları belirlenmiştir. Buna karşın, doz miktarının azalmasının hücre döngüsü proliferasyonunda olumsuz etkilere sahip olmasinın yanında çok sayıda ve farklı tipte kromozomal aberasyonlara sebep olduğu belirlenmiştir. Çalışmada kullanılan 1250 ve $1000 \mathrm{mg} / \mathrm{L}$ 'lik l-karnitin dozunun hem mitotik aktiviteyi teşvik etmek suretiyle hücre bölünmesini artırdığı hem de ekzojen l-karnitinin kromozom yapısı üzerinde sebep olabileceği muhtemel aberasyonları inhibe etmek suretiyle kromozomal yapının stabilitesini korumaya yardımcı olduğu ortaya konulmuştur. Buna karşın, $500 \mathrm{mg} / \mathrm{L}$ 'lik l-karnitin dozunun hücrelerde toksik etkiye sahip olduğu, mitotik indeksi baskıladığ inhibe ederek hücre ölümüne sebep olmak kaydıyla kromozom yapısı üzerinde farklı tipte ve çok yüksek oranda anormalliklere sebep olmasından dolayı, 1karnitinin yüksek dozlarda kullanılmasının düşük dozlarına oranla hücre bölünmesi üzerinde de olumlu etki göstereceği düşünülmektedir.

\section{TEŞEKKÜR}

Bu çalışma, Burdur Mehmet Akif Ersoy Üniversitesi Fen Edebiyat Fakültesi Moleküler Biyoloji ve Genetik Bölümü lisans öğrencisi Fatma GÜRBÜZ'ün, TÜBİTAK 2209/A Üniversite Öğrencileri Yurt İçi Araştırma Projeleri Destekleme Programı kapsamında aldığı destek ile yürütülmüştür. Katkılarından dolayı TÜBİTAK başta olmak üzere, Burdur Mehmet Akif Ersoy Üniversitesi Fen Edebiyat Fakültesi Moleküler Biyoloji ve Genetik Bölümü lisans öğrencileri Mert KARTAL, Aysel UNAT ve Zehra KAYA'ya teşekkür ederiz.

\section{KAYNAKLAR}

Akinboro A, Bakare AA 2007. Cytotoxic And Genotoxic Effects Of Aqueous Extracts Of Five Medicinal

Plants On Allium cepa Linn. Journal of Ethnopharmacology, 112(3):470-475.

Angelidis AS, Smith GM 2003. Role Of The Glycine 
Betaine And Carnitine Transporters In Adaptation of Listeria Monocytogenes To Chill Stress In Defined Medium. Applied Environmental Microbiology, 69: 7492-7498.

Arslan C 2006. L-Carnitine and Its Uses A Feed Additive in Poultry Feding A Review. Revue de Médicine Véterinaire, 157(3): 134-142.

Baderna D, Maggioni S, Boriani E, Gemma S, Molteni M, Lombardo A, Colombo A, Bordonali S, Rotella G, Lodi M, Benfenati E 2011. A Combined Approach to Investigate The Toxicity Of An Industrial Landfill's Leachate: Chemical Analyses, Risk Assessment And In Vitro Assays. Environmental Research, 111(4): 603-613.

Barberio A, Voltolini JC, Mello MLS 2011. Standardization of Bulb and Root Sample Sizes For The Allium cepa Test. Ecotoxicology, 2011(20): 927935. doi: 10.1007/s10646-011-0602-8.

Cabrera GL, Rodriguez DMG 1999. Genotoxicity of Soil From Farmland Irrigated With Wastewater Using Three plant Bioassays. Mutation Research Fundamental and Molecular Mechanisms of Mutagenesis, 426: 211-214.

Campos JMS, Viccini LF, Andrade LF, Davide LC, Rodrigues GS 2009. Genetic Toxicology And Environmental Mutagenesis In Allelopathic Interactions. (Plant Bioassays, Studium Press, Houston: Eds. Narwal SS, Sampietro DA, Catalán, CAN, Vattuone MA, Politycka B) 1e344.

Carter HE, Bhattacharya PK, Weidman KR, Fraenkel G 1952. Chemical Studies on Vitamin BT-Isolation And Characterization As Carnitine. Archives of Biochemistry and Biophysics, 38: 405-416.

Chen W, Huang YC, Shultz TD 1998. Urinary, Plasma, and Erythrocyte Carnitine Concentrations During Transition To A Lactoovovegetarian Diet With Vitamin B-6 Depletion And Repletion in Young Adult Women. The American Journal of Clinical Nutrition, 67: 221-230.

Çitil M 2002. Veteriner Hekimlikte Karnitin. Kafkas Üniv. Veteriner Fakültesi Dergisi, 8 (1): 77-82.

Di Giacomo C, Latteri F, Fichera C, Sorrenti V, Campisi A, Castorina C, Russo A, Pinturo R, Vanella A 1993. Effect Of Acetyl L- Carnitine On Lipid Peroxidation And Xanthine Oxidase Activity in Ratskeletal Muscle. Neurochemical Research, 18: $1157-1162$.

Duncan DB 1955. Multiple Range and Multiple F Tests. Biometrics, 11:1

Firbas P, Amon T 2013. Allium Chromosome Aberration Test for Evaluation Effect of Cleaning Municipal Water With Constructed Wetland (CW) In Sveti Tomaž, Slovenia. Journal of Bioremediation and Biodegradation, 4: 189-193. doi:10.4172/2155-6199.1000189

Fiskesjö G 1995. Allium test: In Vitro Toxicity Testing Protocols. Methods in Molecular Biology, 43: 119127.
Fox DP 1969. Some Characteristics of The Cold Hydrolysis Technique For Staining Plant Tissues By The Feulgen Reaction. J of Histochemistry and Cytochemistry, 17(4): 266-272.

Franken J, Bauer FF 2010. Carnitine Supplementation Has Protective And Detrimental Effects In Saccharomyces Cerevisiae That Are Genetically Mediated. FEMS Yeast Research, 10: 270-281. doi: 10.1111/j.1567-1364.2010.00610.x

Gadano A, Gurni A, López P, Ferraro G, Carballo M 2002. In Vitro Genotoxic Evaluation Of The Medicinal Plant Chenopodium ambrosioides L. Journal of Ethonopharmacology, 81: 11-16.

Golzar Adabi SH, Cooper RG, Ceylan N, Çorduk M 2011. L-Carnitine And Its Functional Effects Inpoultry Nutrition. Worlds Poultry Science Journal, 67: 277-288.

Grant WF 1978. Chromosome Aberrations In Plants As A Monitoring System. Environmental Health Perspectives, 22: 37-43

Grant WF 1994. The Present Status of Higher Plant Bioassays For Detection of Environmental Mutagens. Mutation Research, 310: 175-185.

Grant WF 1999. Higher Plant Assays For The Detection of Chromosomal Aberrations And Gene Mutation: A Brief Historical Background On Their Use For Screening And Monitoring Environmental Chemicals. Mutation Research, 426: 107-112.

Gulewitsch W, Krimberg R 1905. On Carnitine. HoppeSeyler's Zeitschrift Fur Physiologische Chemie, 45: 326-330, 10.1161/ATVBAHA.114.303252

IBM Corp. Released 2013. IBM SPSS Statistics for Windows, Version 22.0. Armonk, NY: IBM Corp.

Ivanova E, Staikova T, Velcheva I, Kostadinovn K 2003. Somatostatic Effect of Heavy Metal Contaminated Waters In The Region of The Town Of Panagjurishte, Bulgaria. Journal of Environmental Protection, 4(2): 284-287.

Kihlman BA 1977. Root Tips of Vicia faba For The Study Of The Induction Of Chromosomal Aberrations. (Handbook of mutagenicity test procedures, Amsterdam, New York, Oxford: Elsevier scientific publishing company: Eds. Kilbey BJ, Legator M, Nichols W, Ramel C), 389-400.

Kopec B, Fritz IB 1973. Comparison Of Properties Of Carnitine Palmitoyltransferase I With Dose Of Carnitine Palmitoyltransferase II, And Prepations Of Antibodies To Carnitine Palmitoyltransferases. The Journal of Biological Chemistry, 248: 40694079.

Kumar DS, Chakrabarty D, Verma AK, Banerji BK 2011. Gamma Ray Induced Chromosomal Aberrations And Enzyme Related Defense Mechanism In Allium cepa L., Caryologia, 64(4): 388-397.

Lehninger AL, Nelson DL, Cox MM 1993. Principles of Biochemistry. Yayın No: 2, New York, 1013s.

Leme DM, Marin-Morales MA 2009. Allium cepa Test 
In Environmental Monitoring: A Review On Its Application. Mutation Research, 682(1): 71-81.

Levan A 1938. The Effect of Colchicines On Root Mitoses in Allium. Hereditas, 24: 471-486.

Maluszynska J, Juchimiuk J 2005. Plant Genotoxicity: A Molecular Cytogenetic Approach In Plant Bioassays. Plant Genotoxicity, 56: 177-184.

Mercykutty VC, Stephen J 1980. Adriamycin Induced Genetic Toxicity As Demonstrated by Allium cepa Test. Cytologia 45(4):769-777.

Melone MAB, Valentino A, Margarucci S, Galderisi U, Giordano A, Peluso G 2018. The Carnitine System And Cancer Metabolic Plasticity. Cell Death Dis, http://doi:10.1038/s41419-018-0313-7.

Monograph 2005. L-Carnitine. Alternative Medicine Review, 10: 42-50.

Mroczkowska JE, Gala HJ, Nalecz MJ, Nalecz KA 1997. Evidence For An Asymmetrical Uptake Of LCarnitine In The Blood-Brain Barrier in Vitro. Biochemistry and Biophysics Research Communication, 241: 127-131.

Nefic H, Musanovic J, Metovic A, Kurteshi K 2013. Chromosomal And Nuclear Alterations In Root Tip Cells of Allium cepa L. Induced By Alprazolam. Medical Archives, 67(6): 388-392.

Pacilli A, Calienni M, Margarucci S, D'Apolito M, Petillo O, Rocchi L, Pasquinelli G, Nicolai R, Koverech A, Calvani M, Peluso G, Montanaro L 2013. Carnitine-Acyltransferase System Inhibition, Cancer Cell Death, And Prevention Of Myc-Induced Lymphomagenesis. Journal of National Cancer Institute, 105(7):489-498.

Pathiratne A, Hemachandra CK, De Silva N 2015. Efficacy of Allium cepa Test System For Screening Cytotoxicity And Genotoxicity Of Industrial Effluents Originated From Different Industrial Activities. Environmental Monitoring Assess, 187(12) : 730 .

Reznick AZ, Kagan VE, Ramsey R, Tsuchiya M, Khwaja S, Serbinova EA, Packer L 1992. Antiradical Effects In L-Propionyl Carnitine Protection of The Heart Against IschemiaReperfusion Injury: The Possible Role of Iron Chelation. Archives of Biochemistry and Biophysics, 296: 394-401.

Ribas GS, Vargas CR, Wajner M 2014. L-Carnitine Supplementation As A Potential Antioxidant Therapy For Inherited Neurometabolic Disorders. Gene, 533(2): 469-476.

Ricciardi MR, Mirabilii S, Allegretti M, Licchetta R, Calarco A, Torrisi MR, Foà R, Nicolai R, Peluso G, Tafuri A 2015. Targeting The Leukemia Cell Metabolism By The Cptia Inhibition: Functional Pre-Clinical Effects In Leukemias. Blood, 126:1925-1929.

Rojas E, Herrera, LA, Sordo, M, Gonsebatt, ME, Montero R, Ostrosky-Wegman P 1993. Mitotic Index and Cell Proliferation Kinetics For
Identification of Antineoplastic Activity. Anticancer Drugs, 4(6): 637-640.

Santoro A, Lioi MB, Monfregola J, Salzano S, Rocchina Barbieri R, Ursini MV 2005. L-Carnitine Protects Mammalian Cells From Chromosome Aberrations But Not From Inhibition Of Cell Proliferation Induced By Hydrogen Peroxide. Mutation Research, 587:16-25.

Schulze E, Kirschner M 1986. Microtubule Dynamics In Interphase Cells. Journal of Cell Biology, 102(3):1020-1031

Sehgal R, Roy S, Kumar VL 2006. Evaluation of Cytotoxic Potential of Latex of Calotropis procera and Podophyllotoxin In Allium cepa. Biocell, 30(1): 9-13.

Sharma CB, Paneerselvan SR 1990. Genetic Toxicity of Pesticides In Higher Plant Systems. Critical Reviews in Plant Science, 9: 409-442.

Sharma S, Vig AP 2012. Genotoxicity of Atrazine, Avenoxan, Diuron And Quizalofop-P-Ethyl Herbicides Using The Allium cepa Root Chromosomal Aberration Assay. Terrestrial and Aquatic Environmental Toxicology, 6: 90-95.

Shug AL, Schmidt MJ, Golden GT, Fariello RT 1982. The Distribution And Role of Carnitine In The Mammalian Brain. Life Sciences, 31: 2869-2874.

Surai PF 2015. Antioxidant Action Of Carnitine: Molecular Mechanisms and Practical Applications. EC Veterinary Science, 2: 66-84.

Teixeira RO, Camparoto ML, Mantovani MS, Vicentini VEP 2003. Assessment Of Two Medicinal Plants, Psidium guajava L. and Achillea millefolium L., Invitro And In-vivo Assays. Genetics and Molecular Biology, 26(4): 551-555.

Trushin M, Ratushnyak AY, Arkharova IA, Ratushnyak AA 2013. Genetic Alterations Revealed In Allium Cepa-Test System Under The Action Of Some Xenobiotics. World Applied Sciences Journal, 22: 342-344.

Vanella A, Russo A, Acquaviva R, CampisiA, Di Giacomo C, Sorrenti V, Barcellona ML 2000. L-Propionyl-Carnitine As Superoxide Scavenger, Antioxidant, And Cleavage Protector. Cell Biology and Toxicology, 16: 99-104.

Vaz FM, Wanders RJ 2002. Carnitine Biosynthesis In Mammals. Biochemical Journal, 361: 417-429.

Vicentini VEP, Camparoto ML, Teixeira RO, Mantovani MS 2001. Averrhoa carambola L., Syzygium cumini (L.) Skeels and Cissus sicoydes L.: Medicinal Herbal Tea Effects on Vegetal And Animal Test Systems. Acta Scientiarum, 23: 593598.

Zakzok FB, Hegazy HM, Yosef TA, Gomaa GM 2018. Mitigating Impact Of L-Carnitine Against Dimethoate Induction Of Hepatic And Testicular Genotoxicity In Rats: The Role Of Oxidative Stress. Toxin Reviews, http://doi:10.1080/ 15569543.2018. 1522645 . 